\title{
Educação e conversão religiosa: os batistas de Richmond e o Colégio Taylor-Egídio de Jaguaquara, Bahia - 1882-1936
}

João Pedro Gonçalves Araújo

Curso: Doutorado em Sociologia

Data: 28 de agosto de 2006

Orientador: Prof. Dr. João Gabriel Lima Cruz Teixeira

\section{Resumo}

Esta tese tem como intenção contribuir para o processo de se conhecer os esforços educacionais realizados no Brasil por grupos religiosos. A partir de uma análise histórica do processo da criação de escolas pelos batistas no Brasil, mostra-se, sincronicamente, as dificuldades internas e externas que a denominação batista enfrentou para vencer os seus próprios preconceitos quanto à educação, bem como a falta de recursos e as dificuldades próprias de uma população que, acostumada a não ter escola, achava que isso era um produto de luxo, coisa para ricos.

Intentando evangelizar o brasileiro por todas as formas imaginadas, os batistas criaram as suas escolas, para que, através delas, mais pessoas fossem alcançadas. A presença de uma escola batista em uma cidade do interior do Estado da Bahia estimulou a criação de outras escolas. Sendo uma instituição criada por religiosos, nem por isso transformou seus alunos à sua imagem e semelhança como se poderia imaginar, ou, inicialmente, pretendiam os seus idealizadores.

Palavras-chave: educação, protestantismo, protestantismo de imigração, protestantismo de missão, conversão religiosa, igreja, 
batistas, presbiterianos, metodistas, evangelismo, proselitismo, missionários, pastores, catolicismo, jesuítas, escolas, Colégio Taylor-Egídio, Junta de Richmond, Jaguaquara, Bahia, São Paulo, Estados Unidos, finanças.

\section{Burocracia e participação: a experiência do Orçamento Participativo em Porto Alegre}

Marianne Nassuno

Curso: Doutorado em Sociologia

Data da defesa: 29 de agosto de 2006

Nome da orientadora: $\operatorname{Prof}^{\mathrm{a}} \mathrm{Dr}^{\mathrm{a}}$ Maria Francisca Pinheiro Coelho

\section{Resumo}

Este trabalho discute a tensão entre burocracia e participação a partir da análise da estrutura, processos, documentos e pessoas que realizaram a institucionalização da participação no Orçamento Participativo de Porto Alegre (OPPA), no período entre 1989 e 2004.

Constata-se a existência de um quadro administrativo participativo em Porto Alegre com características diversas, embora não opostas ao tipo ideal weberiano de burocracia. Os elementos do tipo ideal da burocracia, embora presentes no quadro administrativo do OPPA, não são suficientes para institucionalizar a participação. A tensão entre burocracia e participação é confirmada com uma análise do conceito de participação segundo o pensamento de diversos autores e tendo como referência os conceitos de igualdade e liberdade. 